\title{
IDENTIFIKASI BAKTERI DARI PUPUK ORGANIK CAIR ISI RUMEN SAPI
}

\author{
Sri Suci Damayanti ${ }^{1}$, Oom Komala ${ }^{{ }^{*}}$, E.Mulyati Effendi ${ }^{1}$ \\ ${ }^{1}$ Program Studi Biologi FMIPA Universitas Pakuan, Bogor. \\ "e-mail: oomkomala@unpak.ac.id
}

diterima: 16 Juli 2018; direvisi: 23 Agustus 2018; disetujui: 4 September 2018

\begin{abstract}
ABSTRAK
Teknologi pengolahan limbah merupakan hal yang tidak kalah penting bagi usaha Rumah Potong Hewan (RPH). Berbagai usaha dan teknologi telah dilakukan untuk menangani masalah limbah ini, terutama untuk limbah rumen di RPH. Salah satunya adalah memanfaatkan limbah tersebut sebagai bahan pupuk organik. Bakteri rumen sapi adalah bakteri yang bersumber dari isi rumen sapi, dengan teknis pengembangan secara sederhana dan murah. Bakteri ini sangat membantu petani dalam peningkatan dan pengembangan pertanian yang berwawasan pada pelestarian kesuburan tanah dan sumber daya alam. Penelitian ini bertujuan untuk mengidentifikasi bakteri dan mengetahui keanekaragaman, sifat, dan karakteristik bakteri dari pupuk organik cair isi rumen sapi. Metode yang dilakukan dengan cara mengamati morfologi koloni, seleksi dan pemurnian koloni, pewarnaan Gram, pewarnaan Spora, dan pengujian biokimia. Dari empat isolat yang teridentifikasi terdapat dua genus bakteri yaitu tiga isolat RS1a, RS2a, RS2b termasuk genus Bacillus sp. yang bersifat aerobik dan satu isolat RS1b termasuk genus Lactobacillus sp. yang bersifat fakultatif anaerob. Keempat isolat bakteri mampu tumbuh optimum pada $\mathrm{pH} 6,5$ dan suhu $37^{\circ} \mathrm{C}$ yang bersifat homofermentatif.
\end{abstract}

Kata Kunci: Bakteri, pupuk organik cair, rumen sapi

\section{IDENTIFICATION BACTERI OF LIQUID ORGANIC FERTILIZER THE CONTENTS OF COW RUMEN}

\begin{abstract}
Waste treatment technology is not less important for the business of Slaughterhouse (RPH). Various businesses and technologies have been done to handle this waste problem, especially for the rumen waste in RPH. One of them is utilizing the waste as an organic fertilizer. Bovine rumen bacteria are bacteria that originate from the contents of bovine rumen, with simple and inexpensive development techniques. This bacterium helps farmers in improving and developing an insightful agriculture on the preservation of soil fertility and natural resources. The study aims to identify bacteria and find out the diversity, properties, and characteristics of bacteria from the liquid organic content of rumen cows. Methods undertaken by observing colony morphology, colony selection and purification, Gram staining, spores staining, and biochemical testing. Of the four isolates identified there are two bacterial genus, three isolates RS1a, RS2a, RS2b including the genus Bacillus sp. aerobic and an isolates of RS1b including the genus Lactobacillus sp. the facultative of anaerobic. The four isolates of bacteria are able to grow optimum at $\mathrm{pH} 6.5$ and the temperature of $37^{\circ} \mathrm{C}$ is homofermentative.
\end{abstract}

Key words: bacteria, cow rumen, liquid organic fertilizer 


\section{PENDAHULUAN}

Limbah ternak adalah sisa buangan dari suatu kegiatan usaha peternakan seperti usaha pemeliharaan ternak, rumah potong hewan, pengolahan produk ternak, dll. Limbah tersebut meliputi limbah padat dan limbah cair seperti feses, urine, sisa makanan, embrio, kulit telur, lemak, darah, bulu, kuku, tulang, tanduk, isi rumen, dll (Sihombing, 2000).

Berbagai manfaat dari limbah ternak, apalagi limbah tersebut dapat diperbaharui (renewable) selama ada ternak. Limbah ternak masih mengandung nutrisi atau zat padat yang potensial untuk dimanfaatkan. Limbah ternak kaya akan nutrient (zat makanan) seperti protein, lemak, bahan ekstrak tanpa nitrogen (BETN), vitamin, mineral, mikroba atau biota, dan zat-zat yang lain. Limbah ternak dapat dimanfaatkan untuk bahan makanan ternak, pupuk organik, energi dan media berbagai tujuan (Sihombing, 2000).

Rumen termasuk sistem pencernaan berbentuk seperti sebuah kantung, yang berfungsi sebagai tempat untuk mengolah pakan dengan bantuan mikroba. Mikroba rumen terdiri dari bakteri, protozoa dan jamur/fungi (Czerkawski, 1986), yang mayoritas hidup dalam suasana anaerob dan sebagian dalam suasana fakultatif anaerob. Isi rumen merupakan salah satu limbah rumah potong hewan yang belum dimanfaatkan secara optimal bahkan ada yang dibuang begitu saja sehingga menimbulkan pencemaran lingkungan. Limbah ini sebenarnya sangat potensial bila dimanfaatkan sebagai bahan pakan ternak, pupuk organik.

Penelitian ini bertujuan untuk mengidentifikasi bakteri dan mengetahui keanekaragaman, sifat, dan karakteristik bakteri dari pupuk organik cair isi rumen sapi.

\section{BAHAN DAN METODE Bahan dan Alat}

Bahan yang digunakan adalah isi rumen sapi, glukosa, air cucian beras, air mineral, metilen blue, iodin, alkohol 95\%, safranin, fuchsin, kristal violet, aquades, $\mathrm{NaCl}$ fisiologis, media agar darah, Nutrient Broth, Nutrien Agar, media SIM (Sulfit Indol Motility), $\mathrm{H}_{2} \mathrm{O}_{2} 3 \%$.

Alat yang digunakan adalah ember/drum plastik berukuran 10 liter 1 buah, kertas ukuran $1 \mathrm{~m}$, bunsen, korek api, tabung reaksi dan raknya, tabung durham, ose, objek glass dan penutupnya, kapas, kertas alumunium foil, kassa, karet, cawan petri, neraca analitik, kertas saring, spatula, labu erlenmeyer, pipet tetes, magnetic sterer, $\mathrm{pH}$ meter, thermometer, beker glass, kertas label, pinset, kompor pemanas, oven autoklaf, inkubator, laminar air flow, mikroskop, buku identifikasi.

\section{Metode \\ Pembuatan pupuk organik cair}

Isi rumen sapi sebanyak $5 \mathrm{~kg}$ dicampur dengan $1 / 2 \mathrm{~kg}$ glukosa, $5 \mathrm{~L}$ air cucian beras, dan 3L air mineral di dalam di ember yang berukuran 10L, diaduk sampai merata. Ember yang berisi isi rumen sapi dan kombinasinya ditutup dengan menggunakan kertas yang berukuran $1 \mathrm{~m}$, dan dibiarkan selama 15 hari pada ruangan terbuka (difermentasi).

\section{Sterilisasi Alat}

Sebelum penelitian, dilakukan sterilisasi alat-alat terlebih dahulu, yaitu dengan cara alat-alat dicuci dengan detergen, dibilas dengan air, dikeringkan, dibungkus dengan menggunakan kertas, dan disterilisasi di autoklaf dengan suhu $121^{\circ} \mathrm{C}$ dan tekanan 15 psi (per square inchi) selama 15 menit. Kemudian dikeringkan di dalam oven pada suhu $120^{\circ} \mathrm{C}$ selama 1 jam. Untuk alat yang tidak tahan terhadap panas tinggi cukup disterilisasi dengan alkohol $70 \%$.

\section{Pembuatan Media Isolasi Media NB}

Nutrient Broth powder 13 g dilarutkan dengan $1000 \mathrm{ml}$ aquadest dalam labu erlenmeyer, kemudian dipanaskan sambil digoyang hingga mendidih selama 1-2 menit dan membentuk larutan yang sempurna. Dituangkan dalam tabung reaksi @ 8 mldan 
disterilkan di dalam autoklaf pada suhu $121^{\circ} \mathrm{C}$ dan tekanan 15 Ibs selama 15 menit.

\section{Media agar darah}

Blood Agar sebanyak 40 g dilarutkan dengan $1 \mathrm{~L}$ air suling dan dipanaskan sampai mendidih sambil diaduk, disterilkan dengan autoklaf pada suhu $121^{\circ} \mathrm{C}$, tekanan $15 \mathrm{lbs}$ selama 15 menit. Setelah disterilkan tambahkan darah domba segar sebanyak 50 $\mathrm{mL}$, dicampur rata, dituang ke cawan petri sebanyak $15 \mathrm{~mL}$.

\section{Media NA}

Nutrient Agar powder 23 g dilarutkan pada $1000 \mathrm{ml}$ aquadest dalam labu erlenmeyer, kemudian dipanaskan sambil digoyang hingga mendidih selama 1-2 menit dan membentuk larutan yang sempurna. Disterilkan dalam autoklaf pada suhu $121^{\circ} \mathrm{C}$ dan tekanan 15 lbs selama 15 menit. Setelah steril dituangkan dalam tabung reaksi@5 $\mathrm{ml}$ dan tabung reaksi diletakkan dalam posisi miring $15^{\circ}$ atau ditungkan ke dalam cawan petri @ 20 ml. Setelah Nutrient Agar dalam kemasan tersebut membeku, untuk uji sterilitas di masukkan lebih dulu ke dalam inkubator pada suhu $37^{\circ} \mathrm{C}$ selama 24 jam sebelum media tersebut digunakan.

\section{Medium Sulfit Indol Motility (SIM).}

Media SIM sebanyak $30 \mathrm{~g}$ dilarutkan dengan $1 \mathrm{~L}$ air suling, dipanaskan hingga melarut, setelah itu dimasukkan ke tabung reaksi sebanyak $10 \mathrm{~mL}$, disterilkan dengan autoklaf selama 15 menit pada suhu $121^{\circ} \mathrm{C}$ tekanan 15 lbs.

\section{Isolasi}

Proses isolasi dengan metode gores, yaitu dengan cara 1 ose pupuk cair digoreskan ke dalam media Agar Darah setelah sampel digoreskan, cawan petri dibungkus dengan menggunakan kertas dan diinkubasi pada suhu $37^{\circ} \mathrm{C}$ selama $1-3 \times 24$ jam.

\section{Identifikasi}

Identifikasi jenis-jenis bakteri ini dilakukan dengan beberapa pengujian, diantaranya pengamatan morfologi koloni, seleksi dan pemurnian bakteri, pewarnaan Gram, pewarnaan endospora, pengujian katalase, motilitas, oksidase, ketahanan $\mathrm{pH}$, ketahanan suhu, fermentasi, penggunaan $\mathrm{O}_{2}$.

\section{Pengamatan Morfologi Koloni}

Pengamatan ini dilakukan setelah bakteri pada media Agar Darah diinkubasi selama 48 jam. Pengamatan dilakukan dengan melihat beberapa aspek seperti warna, tepi, dan permukaan koloni pada media Agar Darah.

\section{Seleksi dan Pemurnian Bakteri}

Seleksi dan pemurnian bakteri bertujuan untuk memisahkan dan memperbanyak bakteri yang secara makroskopis terdapat perbedaan pada warna koloni yang telah diinkubasi selama 48 jam. Kemudian dilakukan pemurnian dengan cara mengambil isolat dengan ose pada cawan petri kemudian ditanam pada media NA agar miring pada tabung reaksi dengan metode gores. Diinkubasi pada suhu $37^{\circ} \mathrm{C}$ selama 24 jam.

\section{Pewarnaan Gram}

Pewarnaan Gram digunakan untuk menentukan jenis bakteri Gram positif dan bakteri Gram negatif. Kaca objek dibersihkan dengan alkohol sehingga bebas dari lemak, difiksasi di atas api spirtus sampai kering, diberi satu tetes $\mathrm{NaCl}$ fisiologis. Bakteri dari media NA diambil dengan jarum ose, diletakkan pada tetesan $\mathrm{NaCl}$ fisiologis, dicampur hingga merata. Dibiarkan mengering diudara dan fiksasi di atas api. Diteteskan 2-3 tetes larutan kristal violet, biarkan selama 3 menit, dibuang larutan kristal violet diteteskan larutan lugol satu tetes dan dibiarkan selama 1 menit. Preparat dibilas dengan alkohol 96\% sampai jernih, dicuci dengan air mengalir sampai bersih. Terakhir ditetesi dengan safranin dan dibiarkan selama 2 menit lalu dibilas dengan air mengalir dan dikeringkan. Diamati di bawah mikroskop. Warna ungu untuk bakteri Gram positif dan warna merah untuk bakteri Gram negatif. 


\section{Pewarnaan Spora}

Pewarnaan spora digunakan untuk mengamati bakteri yang berspora Menurut Waluyo (2004) endospora tidak mudah diwarnai dengan zat pewarna pada umumnya.

Prosedur pewarnaan spora menurut Klein adalah sebagai berikut:

1. Disediakan suspensi biakan mikroba berumur 48-72 jam dalam larutan garam fisiologis.

2. Ditambahkan ke dalam suspensi tersbut sama banyaknya larutan karbol fuchsin.

3. Dipanaskan dalam pemanas air pada suhu $80^{\circ} \mathrm{C}$ selama 10 menit.

4. Dibuat preparat dari campuran tersebut dan difiksasi.

5. Dicelupkan ke dalam asam sulfat $1 \%$ selama 1-2 detik.

6. Dicuci dengan air.

7. Dicat dengan larutan methylene blue selama 3 menit.

8. Dicuci kembali dengan air kemudian dikeringkan dan diamati di bawah mikroskop.

Diperhatikan bagaimana letaknya spora itu dalam sel, kemungkinannya adalah terminal, sub terminal, dan sentral. Bentuk spora bulat atau lonjong. Spora berwarna merah dan badan bakteri berwarna biru.

\section{Uji Katalase}

Uji katalase berguna dalam mengidentifikasi kelompok bakteri yang dapat menghasilkan enzim katalase. Dilakukan dengan cara di atas kaca objek ditetesi satu tetes $\mathrm{H}_{2} \mathrm{O}_{2} 3 \%$, ditambahkan koloni bakteri dan langsung diamati terjadinya penguraian hidrogen peroksida. Dinyatakan positif bila menghasilkan enzim katalase yang ditandai dengan terbentuknya gelembung udara dan negatif bila tidak ada gelembung udara. Ini terjadi karena bakteri tersebut apabila ditambahkan hidrogen peroksida menghasilkan peroksida.

\section{Uji Motilitas}

Uji motilitas digunakan untuk melihat pergerakan bakteri. Dilakukan dengan cara satu ose jarum bakteri ditanam secara tegak lurus di tengah Medium SIM (Sulfit Indol Motility) dengan cara ditusukkan, diinkubasi pada suhu $37^{\circ} \mathrm{C}$ selama 24 jam. Bila pertumbuhan koloni menyebar dan timbul kekeruhan seperti kabut menandakan bakteri bergerak.

\section{Uji Oksidase}

Uji oksidase ini dilakukan dengan cara dibuat preparat ulas pada glass objek ditutup dengan tissue atau kertas saring kemudian diteteskan larutan reagen oksidase. Hasil positif warna violet, dan negatif tidak berwarna.

\section{Uji Ketahanan pH}

Isolat murni dari media NA miring diinokulasi ke dalam cawan petri yang berisi media NA sebanyak 3 medium padat yaitu pada cawan petri $\mathrm{P} 1(\mathrm{pH} 4,5), \mathrm{P} 2(\mathrm{pH} 5,5)$, P3 (pH 6,5) kemudian diinkubasi pada suhu $37^{0} \mathrm{C}$ selama 48 jam. Isolat pada ketiga cawan petri tersebut diamati pertumbuhan koloninya, pada $\mathrm{pH}$ mana yang lebih baik tumbuh.

\section{Uji Ketahanan Suhu}

Isolat murni dari media NA miring diinokulasikan ke dalam tabung yang berisi media cair sebanyak 2 tabung yaitu suhu pada tabung $\mathrm{S} 1\left(10^{\circ} \mathrm{C}\right)$ dan $\mathrm{S} 2\left(37^{\circ} \mathrm{C}\right)$, kemudian diinkubasi selama 1-3 hari. Diamati perubahan kekeruhan media pada masing-masing tabung dan dicatat tabung mana yang tingkat kekeruhannya paling tinggi dan paling rendah. Kekeruhan paling tinggi menunjukkan bahwa bakteri tersebut mampu bertahan dan berkembangbiak pada suhu tersebut.

\section{Uji Fermentasi}

Uji fermentasi dilakukan berbarengan dengan uji produksi gas dengan cara menumbuhkan kultur isolat dalam media cair dalam tabung reaksi yang diberi tabung durham dalam keadaan terbalik untuk menangkap gas yang dihasilkan oleh bakteri selama dalam pertumbuhannya, kemudian diinkubasi pada suhu $30^{\circ} \mathrm{C}$ selama $2-3$ hari 
(Yoni S, dkk, 2010). Uji fermentasi positif jika pada tabung durham tertangkap gas dan hasil negatif jika pada tabung durham tidak terdapat gas.

\section{Uji Penggunaan $\mathrm{O}_{2}$}

Isolat murni dari media NA miring diinokulasi ke dalam media NA tegak sebanyak 3 tabung. Bakteri diinokulasi di bagian permukaan media pada tabung pertama $\mathrm{O} 1$, di bagian tengah media $\mathrm{O} 2$, di bagian dasar media $\mathrm{O} 3$, kemudian diinkubasi pada suhu $37^{0} \mathrm{C}$ selama 1-3 hari. Isolat pada ketiga tabung tersebut diamati pertumbuhannya. Aerob jika biakan hanya berada di permukaan media agar, anaerob jika biakan hanya berada di dasar, dan fakultatif anaerob jika biakan berada dipermukaan dan tengah (Nesti Dwiyani, 2010).

\section{Parameter Penelitian}

Mengidentifikasi bakteri pupuk organik cair isi rumen sapi melalui pengamatan morfologi koloni, seleksi dan pemurnian bakteri, pewarnaan gram, pewarnaan endospora, pengujian katalase, motilitas, oksidase, ketahanan $\mathrm{pH}$, ketahanan suhu, fermentasi, dan penggunaan $\mathrm{O}_{2}$.

\section{Analisis Deskriptif}

Data yang telah diperoleh dari berbagai pengujian yang telah dilaksanakan kemudian dilakukan analisis data secara deskriptif untuk mengidentifikasi bakteri hingga tingkat genera dan berpedoman pada buku Bergey's Manual of Determinative Bacteriology (Holt et al, 1997).

\section{HASIL DAN PEMBAHASAN \\ Isolasi Bakteri}

Berdasarkan hasil isolasi terhadap bakteri dari sampel pupuk organik cair isi rumen sapi didapatkan beberapa koloni yang tumbuh setelah diinkubasi pada suhu $37^{\circ} \mathrm{C}$ selama 1-3 hari. Koloni yang diambil pada sampel sebanyak empat koloni, dua koloni dari plat Agar Darah 1 dan dua koloninya lagi dari plat Agar Darah 2 yang bertujuan untuk mendapatkan jenis sel bakteri yang berbeda.

\section{Identifikasi Genera Bakteri Morfologi Koloni}

Pertama dilakukan identifikasi melihat morfologi koloni. Ciri-ciri koloni yang terdapat pada plat Agar Darah 1 berwarna putih susu, pinggir rata dan jernih, bentuk elavasi cembung, dan untuk plat Agar Darah 2 ciri-ciri koloninya adalah berwarna putih agak krem, mengkilat, pinggir agak keriput.

\section{Pemurnian Bakteri}

Keempat koloni bakteri dimurnikan pada media agar miring NA dan diinkubasi pada suhu $37^{\circ} \mathrm{C}$ selama 24 jam. Koloni yang tumbuh kemudian diidentifikasi dan ditentukan karakteristiknya.

Identifikasi dan karakterisasi koloni bakteri yang tumbuh pada plat media Blood Agar sampel pupuk organik cair isi rumen sapi yang diberi tanda RS1a, RS1b, RS2a, RS2b yang telah diinkubasi pada suhu $37^{\circ} \mathrm{C}$ selama 1-3 hari ini merupakan kunci awal untuk pengujian selanjutnya.

\section{Pewarnaan Gram}

Berdasarkan hasil pengamatan dan pengujian terhadap 4 isolat yang dimurnikan, didapatkan bahwa bakteri yang teridentifikasi dari 3 isolat yaitu RS1a, RS2a, RS2b memiliki ciri-ciri berbentuk basil pendek, tunggal, sepasang/berantai, Gram positif. Sedangkan pada isolat RS1b yang memiliki ciri-ciri bentuk sel basil pendek, tunggal/berantai, Gram positif.

\section{Pewarnaan Endospora}

Keempat sampel bakteri yang telah teridentifikasi kemudian dilakukan uji lanjut dengan pengujian pewarnaan spora yang bertujuan untuk mengetahui bahwa bakteri yang telah berhasil diisolasi ada tidaknya spora. Menurut Waluyo (2008) spora pada bakteri merupakan struktur yang tahan panas dan tahan bahan kimia. Spora sulit untuk diwarnai karena struktur lapisan luar spora yang kuat terhadap zat kimia sehingga dalam proses pewarnaan diperlukan teknik 
pewanaan pada suhu $80^{\circ} \mathrm{C}$. Pemanasan tersebut bertujuan untuk mengembangkan lapisan luar spora sehingga zat warna karbol fuchsin dapat masuk dan mewarnai spora menjadi merah. Dari hasil pengujian endospora dihasilkan bahwa tiga isolat bakteri RS1a, RS2a, RS2b yang telah diwarnai dengan pewarnaan spora menunjukan adanya spora dan satu isolat bakteri RS1b tidak menunjukan adanya spora.

Tabel 1. Identifikasi Koloni dan Bentuk Sel

\begin{tabular}{|c|c|c|c|c|}
\hline \multirow{2}{*}{ Kode } & \multirow{2}{*}{ Ciri Koloni } & \multirow{2}{*}{ Ciri Sel } & \multicolumn{2}{|c|}{ Pewarnaan } \\
\hline & & & Gram & Spora \\
\hline RS1a & $\begin{array}{ll}\text { - } & \text { Bentuk bulat kecil } \\
\text { - } & \text { Warna putih susu agak krem } \\
\text { - } & \text { Pinggir rata dan jernih } \\
\text { - } & \text { Bentuk elavasi cembung } \\
\text { - } & \text { Permukaan mengkilat } \\
\end{array}$ & $\begin{array}{l}\text { - Basil/batang } \\
\text { - Pendek } \\
\text { - Berantai }\end{array}$ & + & + \\
\hline $\mathrm{RS} 1 \mathrm{~b}$ & $\begin{array}{l}\text { - } \quad \text { Bentuk bulat kecil } \\
\text { - Warna putih susu agak krem } \\
\text { - Pinggir rata dan jernih } \\
\text { - Bentuk elavasi cembung } \\
\text { - Permukaan mengkilat }\end{array}$ & $\begin{array}{l}\text { - Basil/batang } \\
\text { - Pendek } \\
\text { - Berantai }\end{array}$ & + & - \\
\hline $\mathrm{RS} 2 \mathrm{a}$ & $\begin{array}{ll}\text { - } & \text { Bentuk bulat kecil } \\
\text { - } & \text { Warna putih agak krem } \\
\text { - } & \text { Pinggir keriput dan jernih } \\
\text { - } & \text { Bentuk elavasi cembung } \\
\text { - } & \text { Permukaan mengkilat } \\
\end{array}$ & $\begin{array}{l}\text { - Basil/batang } \\
\text { - Pendek } \\
\text { - Berantai }\end{array}$ & + & + \\
\hline $\mathrm{RS} 2 \mathrm{~b}$ & $\begin{array}{ll}\text { - } & \text { Bentuk bulat kecil } \\
\text { - } & \text { Warna putih agak krem } \\
\text { - } & \text { Pinggir keriput dan jernih } \\
\text { - } & \text { Bentuk elavasi cembung } \\
\text { - } & \text { Permukaan mengkilat } \\
\end{array}$ & $\begin{array}{l}\text { - Basil/batang } \\
\text { - Pendek } \\
\text { - Berantai }\end{array}$ & + & + \\
\hline
\end{tabular}

Keterangan:

Gram : (+) mengikat kristal violet, (-) tidak mengikat kristal violet

Spora : (+) membentuk spora, (-) tidak membentuk spora

Tabel 2. Pengujian biokimia dan pengamatan fisiologi isolat bakteri

\begin{tabular}{|c|c|c|c|c|c|c|c|c|c|c|}
\hline \multirow[b]{2}{*}{ Kode } & \multirow[b]{2}{*}{ Katalase } & \multirow[b]{2}{*}{ Motilitas } & \multicolumn{3}{|c|}{ PH } & \multicolumn{2}{|c|}{ Suhu } & \multirow[b]{2}{*}{ Tipe Fermentasi } & \multirow[b]{2}{*}{ Gas } & \multirow[b]{2}{*}{ Sifat Sel } \\
\hline & & & 4,5 & 5,5 & 6,5 & $10^{0} \mathrm{C}$ & $37^{0} \mathrm{C}$ & & & \\
\hline RS1a & + & + & + & ++ & +++ & - & + & Homofermentatif & - & Aerobik \\
\hline $\mathrm{RS} 1 \mathrm{~b}$ & - & - & + & ++ & +++ & - & + & Homofermentatif & - & $\begin{array}{l}\text { Fakultatif. } \\
\text { anaerob }\end{array}$ \\
\hline $\mathrm{RS} 2 \mathrm{a}$ & + & + & + & ++ & +++ & - & + & Homofermentatif & - & Aerobik \\
\hline $\mathrm{RS} 2 \mathrm{~b}$ & + & + & + & ++ & +++ & - & + & Homofermentatif & - & Aerobik \\
\hline
\end{tabular}

Keterangan :

Katalase : (+) membentuk gelembung udara, (-) tidak membentuk gelembung udara

Motilitas : (+) motil, (-) non motil

$\mathrm{pH}:(+)$ kurang baik, $(++)$ cukup baik, $(+++)$ sangat baik

Suhu : (-) tidak ada pertumbuhan, $(+)$ ada pertumbuhan

\section{Uji Katalase}

Uji katalase yang telah dilakukan pada keempat isolat yaitu tiga isolat menghasilkan gelembung setelah ditetesi larutan $\mathrm{H}_{2} \mathrm{O}_{2} \quad 3 \%$ dan satu isolat tidak menghasilkan gelembung. Menurut Yoni S $d k k$., (2010) reaksi positif uji katalase ditunjukkan dengan membentuk gelembung- 
gelembung yang berarti ada pembentukan gas oksigen $\left(\mathrm{O}_{2}\right)$ sebagai hasil pemecah $\mathrm{H}_{2} \mathrm{O}_{2}$ oleh enzim katalase yang diproduksi oleh bakteri tersebut. Ketiga isolat bakteri RS1a, RS2a, RS2b menunjukan hasil uji katalase positif karena adanya pemecahan $\mathrm{H}_{2} \mathrm{O}_{2}$ menjadi $\mathrm{O}_{2}$. Sedangkan pada satu isolat bakteri RS1b menunjukkan hasil uji katalase negatif karena tidak adanya pemecahan $\mathrm{H}_{2} \mathrm{O}_{2}$ menjadi $\mathrm{O}_{2}$.

\section{Uji Motilitas}

Uji motilitas merupakan salah satu aspek yang dilihat untuk membuktikan ada tidaknya pergerakan dari isolat bakteri yang diinokulasi pada media SIM agar tegak di bagian tengah. Berdasarkan pengujian yang telah dilakukan keempat isolat bakteri yaitu tiga isolat RS1a, RS2a, RS2b menunjukan adanya penyebaran koloni lebih luas ke bagian lainnya, dan satu isolat RS1b menunjukkan tidak adanya penyebaran koloni, terlihat bakteri koloni menumpuk pada bagian tengah dan hanya tumbuh pada bagian tengah agar tegak saja.

\section{Uji Oksidase}

Uji oksidase ini dilakukan untuk menentukan adanya sitokrom oksidase yang dapat ditemukan pada mikroorganisme tertentu. Mikroorganisme aerobik dan anaerobik fakultatif memiliki enzim sitokrom oksidase dan oksigen sebagai akseptor elektronnya sehingga dalam uji ini akan memberikan hasil uji positif yang ditunjukkan dengan perubahan warna koloni bakteri menjadi biru violet dalam waktu 60 detik setelah penambahan reagen uji. Perubahan warna ini disebabkan sitokrom oksidase mengoksidasikan larutan reagen oksidase. Pada mikroorganisme anaerobik obligat akan memberikan hasil uji negatif yang ditandai dengan tidak terjadi peruabahn warna (Lay, 1994).

Berdasarkan hasil uji oksidase pada keempat isolat bakteri menunjukkan hasil positif yang ditandai adanya perubahan warna biru violet.

\section{Uji Fermentasi}

Menurut Nilam (2005) bakteri asam laktat tipe homofermentatif yaitu bakteri yang menggunakan hampir $85 \%$ gula untuk menghasilkan asam laktat, dan tipe heterofermentatif menghasilkan etanol $\mathrm{CO}_{2}$ selain asam laktat. Keempat isolat yang telah teridentifikasi memiliki tipe fermentasi homofermentatif yang menunjukkan hasil negatif dengan tidak adanya pembentukan gelembung gas $\mathrm{CO}_{2}$ di dalam tabung durham yang diinkubasi pada suhu $37^{\circ} \mathrm{C}$ selama 48 jam. Berdasarkan pengujian tipe fermentasi pada keempat isolat bakteri bersifat homofermentatif yaitu bakteri dengan tipe yang hanya mampu untuk memproduksi asam laktat dan fermentasi gula (Mandingan et al., 2003).

\section{Uji Penggunaan $\mathrm{O}_{2}$}

Beberapa dalam
pertumbuhannya ada yang tidak memerlukan oksigen dan ada yang memerlukan oksigen. Pengujian penggunaan $\mathrm{O}_{2}$ ini dilakukan untuk mengetahui sifat dari masing-masing isolat. Berdasarkan pengujian yang telah dilakukan terhadap keempat isolat bakteri, didapat Isolat bakteri RS1b bersifat fakultatif anaerob hidup dan berkembang biak tanpa atau dengan sedikit oksigen, tumbuh pada bagian tengah dan permukaan media NA tegak yang diinkubasi pada suhu $37^{\circ} \mathrm{C}$ selama 24 jam. dan isolat bakteri RS1a, RS2a, RS2b bersifat aerob disebut juga aerobic sporeformes yang biakan bakterinya hanya tumbuh dipermukaan.

\section{Uji Ketahanan pH}

Umumnya bakteri tumbuh baik pada $\mathrm{pH}$ 7,0 meskipun dapat tumbuh pada kisaran $\mathrm{pH}$ 5,0 - 8,0 (Lay et al., 1999). Berdasarkan pH minimun, optimum, dan maksimum untuk pertumbuhannya, mikroba digolongkan ke dalam mikroba asidofilik, neutrofilik, dan alkalinofilik (Theresia $d k k ., 2008$ ). Mikroba asidofilik tumbuh pada $\mathrm{pH}$ optimal 1,0 - 5,5, mikroba neutrofilik tumbuh pada $\mathrm{pH}$ optimal antara 5,5 - 8,0 , dan mikroba alkalofilik tumbuh pada $\mathrm{pH}$ optimal antara 
8,5 - 11,5. Secara keseluruhan isolat yang berhasil diidentifikasi mampu tumbuh pada $\mathrm{pH} 4,5$, pH 5,5 dan $\mathrm{pH}$ 6,5. Pada pengujian $\mathrm{pH}$ ini bakteri pertumbuhan tertinggi dan baik pada perlakuan 6,5 .

\section{Uji Ketahanan Suhu}

Uji ketahanan suhu ini dilakukan untuk melihat kemampuan bakteri tumbuh. Lay (1999) menyatakan bahwa bakteri terbagi menjadi tiga, yaitu bakteri bersifat psikrofil yang dapat tumbuh pada suhu $0^{\circ} \mathrm{C}-20^{\circ} \mathrm{C}$, mesofil pada kisaran $20^{\circ} \mathrm{C}-50^{\circ} \mathrm{C}$, dan termofil yang dapat tumbuh di atas suhu $50^{0} \mathrm{C}$. Bakteri yang telah teridentifikasi dari keempat isolat memiliki kemampuan bertahan pada suhu $37^{\circ} \mathrm{C}$. Menurut Buckle (1987) pada fase logaritmik sel-sel bakteri akan tumbuh dan membelah diri secara eksponensial sampai jumlah maksimum dan dapat dibantu oleh faktor lingkungan seperti $\mathrm{pH}$, media tumbuh, nutrisi, tempratur, dan kelembaban udara.

Berdasarkan pengamatan morfologi koloni, pewarnaan gram, pewarnaan spora dan uji katalase, uji motilitas, uji oksidase, uji fermentsi, uji ketahanan $\mathrm{pH}$, uji ketahanan suhu, dan uji penggunaan $\mathrm{O}_{2}$. Bakteri yang teridendifikasi disesuaikan dengan buku Bergey's Manual of Determinative Bacteriology, dapat disimpulkan bahwa bakteri isolat RS1a, RS2a, RS2b merupakan bakteri genus Bacillus sp. dan isolat RS1b merupakan genus Lactobacillus sp.

\section{KESIMPULAN DAN SARAN \\ Kesimpulan}

Berdasarkan hasil penelitian yang telah dilakukan dapat disimpulkan: Pada sampel pupuk organik cair isi rumen sapi ditemukan bakteri genus Bacillus yang bersifat aerobik aerobik dan bakteri genus Lactobacillus yang bersifat fakultatif anaerobik. Karakteristik keempat isolat bakteri mampu tumbuh pada $\mathrm{pH}$ 6,5 dan suhu $37^{\circ} \mathrm{C}$ dan bersifat homofermentatif.

\section{Saran}

Perlu dilakukan pengujian lebih lanjut untuk mendapatkan karakteristik bakteri hingga tingkat species, dan aplikasi penggunaan bakteri tersebut sebagai bahan pupuk organik.

\section{DAFTAR PUSTAKA}

Buckle, KA, RA, Edwards, GH Fleet dan M.Wootton. (1987). Ilmu Pangan. UIPress, Jakarta.

Czerkawski, J.W. (1986). An Introduction to Rumen Studies. 1st Ed. Pergamon Press, New York.

Holt. J. G., Kreig, N.R., Bryant M.P., Lapage S.P., Lautrop H., Liston J., Murray R.G.E., Ravin A. W. And Staley, J. T. (1997). The Shorter Bergey's Manual of Determinative Bacteriology. Eight Edition. Baltimore. The Williams and Wilkins Baltimore. 184-218.

Lay, B. W. (1994). Analisis Mikroba di Laboratorium. PT Raja Grafindo Persada: Jakarta.

Lay, B. W. (1999). Analisis mikrobiologi di lboratorium. PT. Raja Grafindo Persada: Jakarta.

Mandingan T. M., Martinko M. J and Parker J. (2003). Brock Biology of Microorganisms. Tent Edition, Prentice Hall. New York.

Nesti Dwiyani S.P. (2010). Isolasi dan Identifikasi Bakteri Asam Laktat dari Usus Ayam. Chanlight's Blog. 12 Juli 2010.

Nilam Fadmaulida Wulandari. (2005). Identifikasi dan Karakterisasi Bakteri Asam Laktat (BAL) dari Makanan Fermentasi. Jurnal Laporan Teknik Bidang Mikrobiologi Pusat Penelitian Bogor-LIPI. Hlm 107.

Sihombing D T H. (2000). Teknik Pengelolaan Limbah Kegiatan/Usaha Peternakan. Pusat Penelitian Lingkungan Hidup Lembaga Penelitian, Institut Pertanian Bogor.

Theresia, T.S., Juni $\mathrm{N}$ dan A. Endang, S. (2008). Microbiologi Umum. Penerbit Universitas Atma Jaya Yogyakarta HIm 200. 
Waluyo, L. (2004). Mikrobiologi Umum. Penerbit Universitas Muhamadiyah Press, Malang

Waluyo Lud. (2008). Teknik Metode Dasar dalam Mikrobiologi. Universitas Muhamaadiyah Malang Pres. Hlm 203.
Yoni Suryani , Astuti, Bernadeta Oktavia dan Siti Umniyati. (2010). Isolasi dan Karakterisasi Bakteri Asam Laktat dari Limbah Kotorab Ayam sebagai agen Probiotik dan Enzim Kolesterol Reduktase. Prosiding Seminar Nasional Biologi 3 Juli 2010. Biologi FMIPA UNY. Hlm 138-147 